Notes and Comments

\title{
Length, weight, and longevity record for Micrurus frontalis (Duméril, Bibron \& Duméril, 1854)
}

\author{
Recorde de comprimento, peso, e longevidade para Micrurus frontalis (Duméril, Bibron \\ \& Duméril, 1854)
}

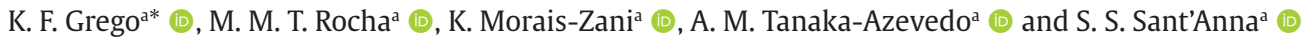 \\ anstituto Butantan, Laboratório de Herpetologia, São Paulo, SP, Brasil
}

The South American triadal coral snakes (snakes with three black rings combined with red and white (or yellow rings) include 17 currently recognized species (Silva Júnior et al., 2003) and one of them is Micrurus frontalis (Figure 1a), which is distributed from the Cerrado formations of Central Brazil (including Sao Paulo and Minas Gerais), and west into Goias, and the Brazilian states of Mato Grosso and Mato Grosso do Sul. To the east, M. frontalis reaches the Atlantic coast in the state of Espirito Santo, and to the S-SW it is found in southern Paraguay (Silva Júnior and Sites Junior, 1999; Campbell and Lamar, 2004 ).

$M$. frontalis venom has a postsynaptic neurotoxin that produces loss of muscle strength and death by respiratory paralysis (Lomonte et al., 2016; Medeiros et al., 2019; Sanz et al., 2019), therefore all accidents must be carefully monitored and evaluated as potentially serious. Its venom is used in the production of Brazilian antielapidic serum, along with the venom of $M$. corallinus. Both species are maintained at the animal facility of the Laboratory of Herpetology at Butantan Institute (LHBI) to produce the anti-venom serum that is distributed to all Brazilian states by the Ministry of Health.

In May 2009, an adult male of $M$. frontalis from the State of São Paulo was donated to the LHBI, weighting $145 \mathrm{~g}$ and with a snout-vent length (SVL) and total length (TL) of $105 \mathrm{~cm}$ and $112 \mathrm{~cm}$, respectively. It was given the identification number Mf 0903.

In nature, $M$. frontalis diet consists of animals with fossorial or cryptozoic habits, as amphisbaenians, some snakes and lizards (Silva Junior, 1995; Roze, 1996; Silva Junior and Aird, 2001). During captivity the specimen was offered thawed snakes in a quantity of $40 \%$ of its body weight for three consecutive weeks, followed by a 15-day break after which the snake was milked (Mendes et al., 2019). The thawed preys offered were from various species, as Sibynomorphus mikanii, S. neuwiedi, Oxyrhopus guibei, Tomodon dorsatus, Bothrops jararaca, B. alternatus, B. jararacussu, B. atrox, Atractus sp, Crotalus durissus, Philodryas sp and Pantherophis guttatus, which were all well accepted by the male (Figure 1b).

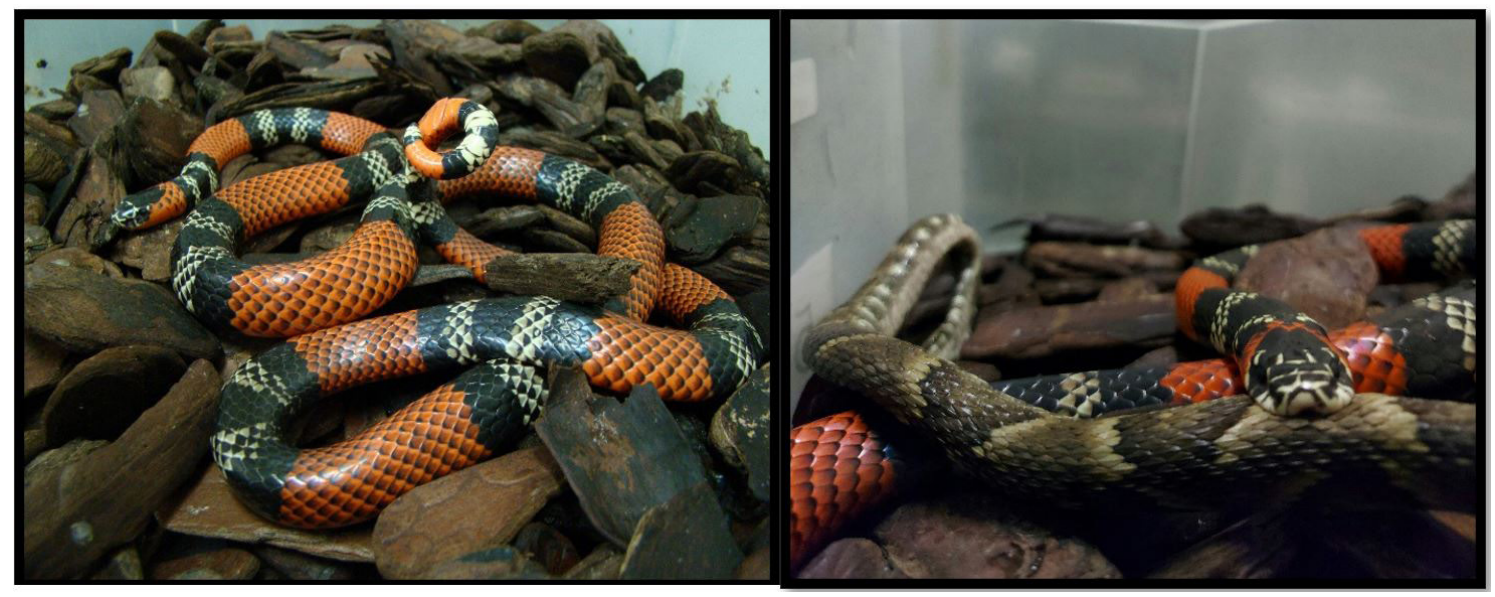

Figure 1. (a) Micrurus frontalis kept in captivity in bark substrate; (b) M. frontalis grasping a thawed Bothrops jararaca.

*e-mail: kathleen.grego@butantan.gov.br

Received: May 3, 2021 - Accepted: June 10, 2021 This is an Open Access article distributed under the terms of the Creative Commons Attribution License, which permits unrestricted use,
distribution, and reproduction in any medium, provided the original work is properly cited. 


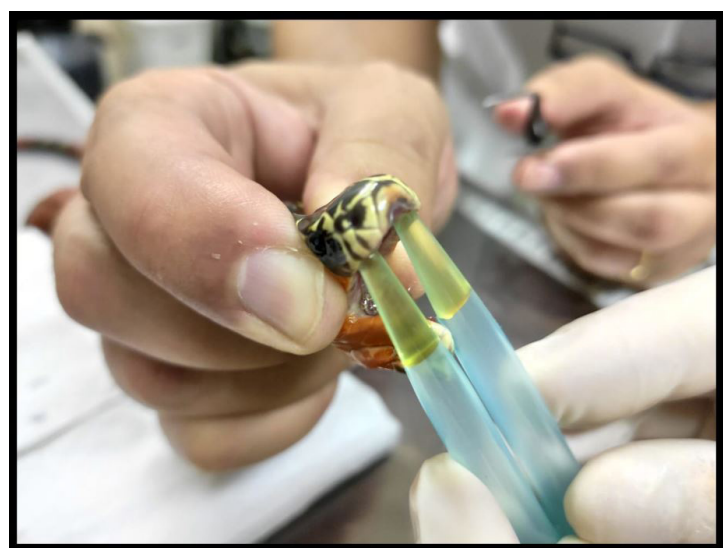

Figure 2. Tips attached to M. frontalis fangs for milking.

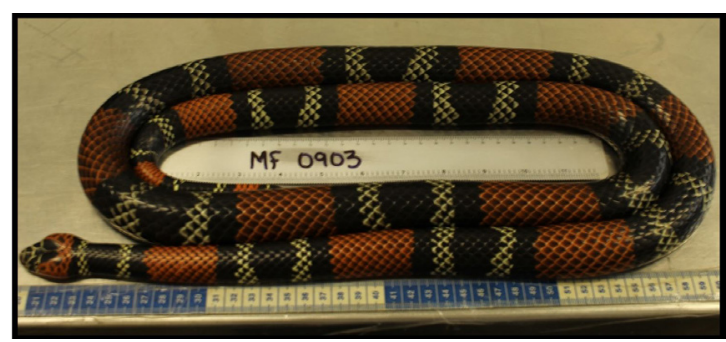

Figure 3. M. frontalis Mf 0903.

To increase milking efficiency, pilocarpine was administered intradermally $\left(10 \mathrm{mg} \mathrm{Kg}^{-1}\right)$ ten minutes before venom extraction (Morais-Zani et al., 2018). Pilocarpine is a natural alkaloid with cholinergic agonist activity that binds to muscarinic receptors inducing secretion from exocrine glands (NCI THESAURUS, 2020). Coral snake venom milking is done with tips attached to the proteroglyphs fangs (Figure 2) and afterwards the venom is pipetted to microtubes.

The specimen was kept in a glass terrarium measuring $120 \mathrm{~cm}$ x $40 \mathrm{~cm}$ x $60 \mathrm{~cm}$, with bark previously treated with chlorine solution as substrate, water ad libitum and a shelter made of palm leaf. For 5 years, this specimen alone was responsible for the venom of $M$. frontalis mixed with the venom of $M$. corallinus for the production of antielapidic serum distributed through the Brazilian Territory. After 8 years in captivity (3123 days) this male died in 2017 due to heart failure, with a TL of $170 \mathrm{~cm}$ and weighing $978 \mathrm{~g}$ (Figure 3). In literature the maximum length recorded for this specie is $164 \mathrm{~cm}$, and to the best of our knowledge this is the record of Micrurus frontalis kept for the longest time in captivity. Oliveira et al. (2006), related a longevity record of 1298 days for $M$. frontalis kept in captivity.

The average amount of venom yielded per $M$. frontalis maintained in captivity at the LHBI in each milking is 70 mg of total venom (from 2018 to present); in contrast, this male yielded $500 \mathrm{mg} /$ milking. Graphic 1 shows the growth (weight and length) of the specimen during its 8 years in captivity.

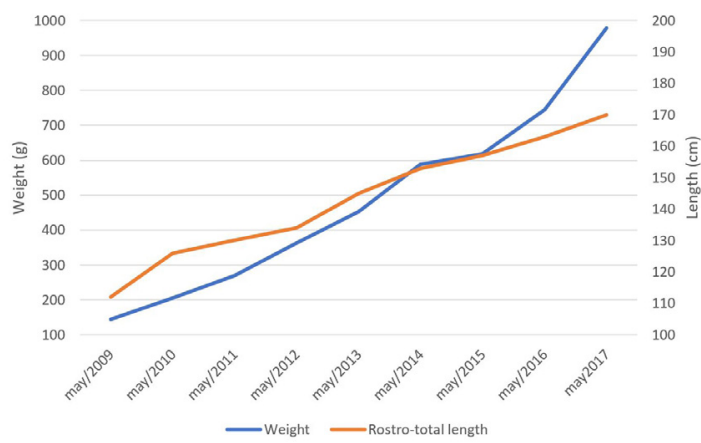

Graphic 1. Growth of Micrurus frontalis during 8 years of captivity.

\section{References}

CAMPBELL, J.A. and LAMAR, W.W., 2004.The venomous reptiles of the Western Hemisphere. Ithaca: Cornell University Press.

LOMONTE, B., REY-SUÁREZ, P., FERNÁNDEZ, J., SASA, M., PLA, D., VARGAS, N. \& CALVETE, J. J., 2016. Venoms of Micrurus coral snakes: Evolutionary trends in compositional patterns emerging from proteomic analyses. Toxicon, vol. 122, pp.7-25. https:// doi.org/10.1016/j.toxicon.2016.09.008.

MEDEIROS, C.R., SOUZA, C.R., LARA, S.N. and GREGO, K.F., 2019. Use of infrared thermography in a case of systemic envenomation by the coral snake Micrurus frontalis (Duméril et al., 1854) in Sao Paulo, Brazil. Toxicon, vol. 163, pp. 70-73. http://dx.doi. org/10.1016/j.toxicon.2019.03.016. PMid:30905699.

MENDES, G.F., STUGINSKI, D.R., LOIBEL, S.M., MORAIS-ZANI, K.D., ROCHA, M.M.T., FERNANDES, W., SANT'ANNA, S.S. and GREGO, K.F., 2019. Factors that can influence the survival rates of coral snakes (Micrurus corallinus) for antivenom production. Journal of Animal Science, vol. 97, no. 2, pp. 972-980. http://dx.doi. org/10.1093/jas/sky467. PMid:30541079.

MORAIS-ZANI, K., SERINO-SILVA, C., GALIZIO, N.C., TASIMA, L.J., PAGOTTO, J.F., ROCHA, M.M.T., MARCELINO, J.R., SANT'ANNA, S.S., TASHIMA, A.K., TANAKA-AZEVEDO, A.M. and GREGO, K.F., 2018. Does the administration of pilocarpine prior to venom milking influence the composition of Micrurus corallinus venom? Journal of Proteomics, vol. 174, pp. 17-27. http://dx.doi. org/10.1016/j.jprot.2017.12.010. PMid:29275045.

NCI THESAURUS, 2020 [viewed 1 November 2020]. Pilocarpine Base [online]. NIH. Available from: https://ncit.nci.nih. gov/ncitbrowser/ConceptReport.jsp?dictionary=NCI Thesaurus\&ns=NCI_Thesaurus $\&$ code $=\mathrm{C} 62068$

OLIVEIRA, L., RIBEIRO, A.C.O., SCARTOZZONI, C.R.R., GERMANO, V.J. and SALOMÃO, M.D.G., 2006. Manutenção de serpentes em cativeiro no Instituto Butantan: I-longevidade do Gênero Micrurus. Publ. Avul. Inst. Pau Brasil, vol. 8, pp. 55-62.

ROZE, J.A. 1996. Coral snakes of the Americas: biology, identification, and venoms. Malabar: Krieger, $328 \mathrm{p}$.

SANZ, L., FREITAS-LIMA, L.N., QUESADA-BERNAT, S., GRAÇA-DESOUZA, V.K., SOARES, A.M., CALDERÓN, L.A., CALVETE, J.J. and CALDEIRA, C.A.S, 2019. Comparative venomics of Brazilian coral snakes: Micrurus frontalis, Micrurus spixii spixii, and Micrurus surinamensis. Toxicon, vol. 166, pp. 39-45. http:// dx.doi.org/10.1016/j.toxicon.2019.05.001. PMid:31091423.

SILVA JUNIOR, N.J. and AIRD, S.D., 2001. Prey specificity, comparative lethality and compositional differences of coral snake venoms. Comparative Biochemistry and Physiology. Toxicology 
E Pharmacology, vol. 128, no. 3, pp. 425-456. http://dx.doi. org/10.1016/S1532-0456(00)00215-5. PMid:11255115.

SILVA JÚNIOR, N.J. and SITES JUNIOR, J.W., 1999. Revision of the Micrurus frontalis complex (Serpentes: elapidae). Herpetological Monograph, vol. 13, pp. 142-194. http://dx.doi.org/10.2307/1467062.

SILVA JUNIOR, N.J., 1995. Molecular systematics and evolution of venoms in the South American 'triad' Coral Snakes Micrurus, elapidae. Provo: Brigham Young University. PhD Dissertation in Zoology.

SILVA JÚNIOR, N.J. \& BUCARETCHI, F. 2003. Mecanismos de ação do veneno elapídico e aspectos clínicos de acidentes. In: J.L.C. CARDOSO, V. HADDAD JUNIOR and F.S. FRANÇA, eds. Animais Peçonhentos no Brasil-Biologia, Clínica e Terapêutica dos Acidentes. 2. ed. São Paulo: Editora Sarvier, pp 99-107. 